\title{
Article \\ Biodegradable Composites with Functional Properties Containing Biopolymers
}

\author{
Miroslawa Prochon ${ }^{1, *(D)}$, Szymon Szczepanik ${ }^{1}$, Oleksandra Dzeikala ${ }^{1}$ (D) and Robert Adamski ${ }^{2}$ \\ 1 Faculty of Chemistry, Lodz University of Technology, Stefanowskiego Str. 16, 90-537 Lodz, Poland; \\ szymon.szczepanik.1@p.lodz.pl (S.S.); oleksandra.dzeikala@p.lodz.pl (O.D.) \\ 2 Faculty of Process and Environmental Engineering, Lodz University of Technology, Wólczanska Str. 213, \\ 90-924 Lodz, Poland; robert.adamski@p.lodz.pl \\ * Correspondence: miroslawa.prochon@p.lodz.pl
}

check for updates

Citation: Prochon, M.; Szczepanik, S.; Dzeikala, O.; Adamski, R. Biodegradable Composites with Functional Properties Containing Biopolymers. Catalysts 2022, 12, 77. https://doi.org/10.3390/ catal12010077

Academic Editor: Anwar Sunna

Received: 16 November 2021

Accepted: 30 December 2021

Published: 11 January 2022

Publisher's Note: MDPI stays neutral with regard to jurisdictional claims in published maps and institutional affiliations.

Copyright: (C) 2022 by the authors. Licensee MDPI, Basel, Switzerland. This article is an open access article distributed under the terms and conditions of the Creative Commons Attribution (CC BY) license (https:// creativecommons.org/licenses/by/ $4.0 /)$.
Abstract: There is a major focus on natural biopolymers of bacterial, animal, or plant origin as ecological materials, replacing petrochemical products. Biologically derived polylactide (PLA), polyhydroxybutyrate (PHB), and polyhydroxyalkanoates (PHA) possess interesting properties, but they are currently too expensive for most applications. Therefore, researchers try to find other biopolymers that are both durable and cheap enough to replace plastics in some applications. One possible candidate is gelatin, which can be transformed into a thin, translucent film that is flexible and has stable and high mechanical properties. Here, we present a method of synthesizing a composite material from gelatin. For preparation of such material, we used gelatin of animal origin (pig skin) with the addition of casein, food gelatin, glycerin, and enzymes as biocatalysts of chemical modification and further extraction of gelatin from collagen. Compositions forming films with homogeneous shapes and good mechanical properties were selected (Tensile strength reaches 3.11 $\mathrm{MPa}$, while the highest value of elongation at break is $97.96 \%$ ). After administering the samples to microbial scaring, the composites completely decomposed under the action of microorganisms within 30 days, which proves their biodegradation.

Keywords: biodegradable materials; natural raw materials; disposable products; eco-friendly composites; gelatin; casein

\section{Introduction}

Polymeric materials, from the earliest years, were widely used in medicine and other areas of industry. Over three thousand different types of medical devices are manufactured from polymers [1]. However, synthetic polymers are often the source of harmful pollutants due to their poor dispersion and excessive exposure to the natural environment [2]. Most modern synthetic polymers are made of petrochemical products and are not biodegradable [3-5]. For example, plastic bags have a negative impact on marine and ocean life [6,7]. Accumulation in the environment of toxic products resulting from the decomposition of such polymeric materials may inhibit plant growth and have a negative impact on ecosystems [8]. Unfortunately, the recycling of plastics has an adverse environmental balance in terms of the energy and resources needed to wash, grind and process the waste [9]. Incineration of plastic waste causes the emission of toxic compounds (e.g., dioxins) to the atmosphere and also entails certain limitations in the availability of effective and economically profitable facilities or devices for burning this type of materials [10]. As a consequence, it leads to the determination of the environmental toxicity of pollutants, known as their ecotoxicity [11-16]. Natural polymers due to their excellent biocompatibility and biocompatibility have been used in medicine for many years [17-22]. Biodegradable polymers have a great potential in many applications including tissue engineering, gene therapy, and regeneration. They can be used in temporary devices for 
implantology and implant coatings [23]. Due to their biocompatibility, biopolymeric hydrogels are also used in application materials (bandages, etc.), as well as for tissue and organ engineering and regeneration (hydrogels, alginates, etc.) [24]. A particularly important achievement in biopolymer technology was the use of biopolymers, both fiber-forming and natural polysaccharide polymers, to create materials for the controlled release of drugs. Natural polymers that are biodegradable inside the body (biohydrolysis) are used to create a temporary therapeutic matrix containing biologically active substances that can be released in a controlled manner [25]. These types of materials, after fulfilling their functions, biodegrade and are naturally removed from the body. Biopolymers have healing properties (biocidal, antioxidant, antiallergic, etc.), which is a great advantage over synthetic materials. Biopolymers are not only biodegradable but non-toxic. It is an important property in all applications, especially in medicine $[26,27]$. Unfortunately, biosourced polymers also have undesirable antigenic properties and are heterogeneous. Natural polymers can be classified based on the method of their synthesis. Examples of polymers derived from biomass include: agropolymers from agricultural raw materials (e.g., starch or cellulose); polymers obtained by the production of microorganisms (polyhydroxybutyrate); conventionally and chemically synthesized polymers from monomers obtained from agricultural raw materials (polylactic acid); and polymers derived from fossil fuels. Only the first three of these categories are considered sustainable [28]. Depending on the application, the required properties and the degradation rate are the basic criteria for selecting a polymer to be used as a biodegradable biomaterial. Plastics are highly resistant to temperature, environmental $\mathrm{pH}$, mechanical deformation, etc. For the polymer material to meet the compostable or biodegradable criteria, and on the other hand to be adequately durable and thermally stable, it should be chemically or physically modified at some stage of its production. One of such solutions was proposed by X. Zhang et al. [29]. Gelatin was modified with a natural phenolic compound from the tannin group. The use of a tannin compound in the amount of $3 \%$ resulted in obtaining a stable structural network even during the thermal treatment process of the polymeric material at $100{ }^{\circ} \mathrm{C}$. The increase in the degree of branching as a result of the grafting of the ingredients used resulted in an increase in the molecular mobility of the gelatin matrix, which consequently made it possible to obtain a protein material with plastic properties. In scientific research, [30,31] gelatin obtained from pig skin was also undergoing esterification with fatty acid. The chemical modification process was catalyzed by a fatty acid in an aqueous medium. In order to optimize the process, the type and concentration of the higher fatty acids used as well as the reaction time were appropriately selected. Based on the determination of the increase in acid concentration under the same conditions of time, the maximum amount of acid that is needed to esterify a given unit of gelatin mass was determined, and on this basis, it turned out that the process of blocking all gelatin hydroxyl groups with the fatty acid used was difficult, which in turn affects the cross-linking processes in gelatin matrices. Other compounds used in gelatin cross-linking are, for example, plant-derived phenolic compounds such as caffeic acid $[32,33]$. Optimization of the time and concentration of the applied acid to the gelatin system resulted in obtaining a different degree of cross-linking of the polymeric material. A lower degree of deformation at higher temperatures was achieved for gelatin cross-linked in this way as shown by rheological analysis.

In this article, we present the method of producing polymer films based on a gelatin matrix with the use of waste skin tissue of animal origin ("WĘDLINKA Sp. z o.o." Wieruszów, Poland). The films were enriched with casein, chitosan, agar, cellulose acetate, and glycerin plasticizer to obtain durable film-like coatings with a uniform shape and good mechanical parameters. In the designed chemical preparation, a specific type of catalyst was proposeda proteolytic enzyme (Novo Unhairing Enzyme NUE $12 \mathrm{MP}$ Activity $8.37 \mathrm{KNPU}$ (E)/g [33] $130,000 \mathrm{LVU} \mathrm{g}^{-1}[34,35]$ and acetic acid. The purpose of the biocatalyst introduced into the mixture with fragments of fractionated collagen tissues was to accelerate the catalytic partial disintegration reaction and obtain a homogeneous mixture. On the other hand, the introduction of the organic acid was aimed at loosening the fibrillar structure of collagen 
fibers without leading to complete conformational denaturation of the roll helix. In this way, we have obtained a composite with the desired performance parameters, thermally stable, with limited water absorption. This type of material could be used in tissue engineering. Potential application of this film is the base for growth factor sequestration, biomimetic composites, scaffolds for bone tissue or basis for bone substitute [36-38].

\section{Results and Discussion}

\subsection{Characterization of Composites}

\subsubsection{Shore Hardness Testing}

Table 1 shows the results of Shore (00) hardness tests' performer for each composition. The same results are summarized in Figure 1. From the graph, it can be seen that the $\mathrm{HO}$ composite has the highest hardness. The reason for this difference between the compositions is the network that formed in the material. As observed in previous research, $\mathrm{HO}$ was the most stable of the tested composites in terms of networks out of all the tested compositions [30]. The stability of its polymer network may be the result of synthesis at acidic $\mathrm{pH}$ with acetic acid, which does not break collagen bonds to the same extent as the sodium base. Therefore, the remaining compositions were mechanically weaker. The increase in hardness and density occurred as a result of the stronger or denser connection of the matrix with the additives and the strengthening due to the increased holding time and temperature [26]. The increase in the gelatin concentration resulted in biopolymer films with greater density and stability, as was reflected in the FTIR analysis.

Table 1. Shore 00 hardness measurements with the standard deviation.

\begin{tabular}{cc}
\hline Composition & $\mathbf{H}_{\mathbf{0 0}} \pm \mathbf{d H}\left[{ }^{\circ} \mathbf{S h}\right]$ \\
\hline HO & $92.3 \pm 1.29$ \\
HA & $87.1 \pm 0.51$ \\
HB & $84.8 \pm 2.13$ \\
\hline
\end{tabular}

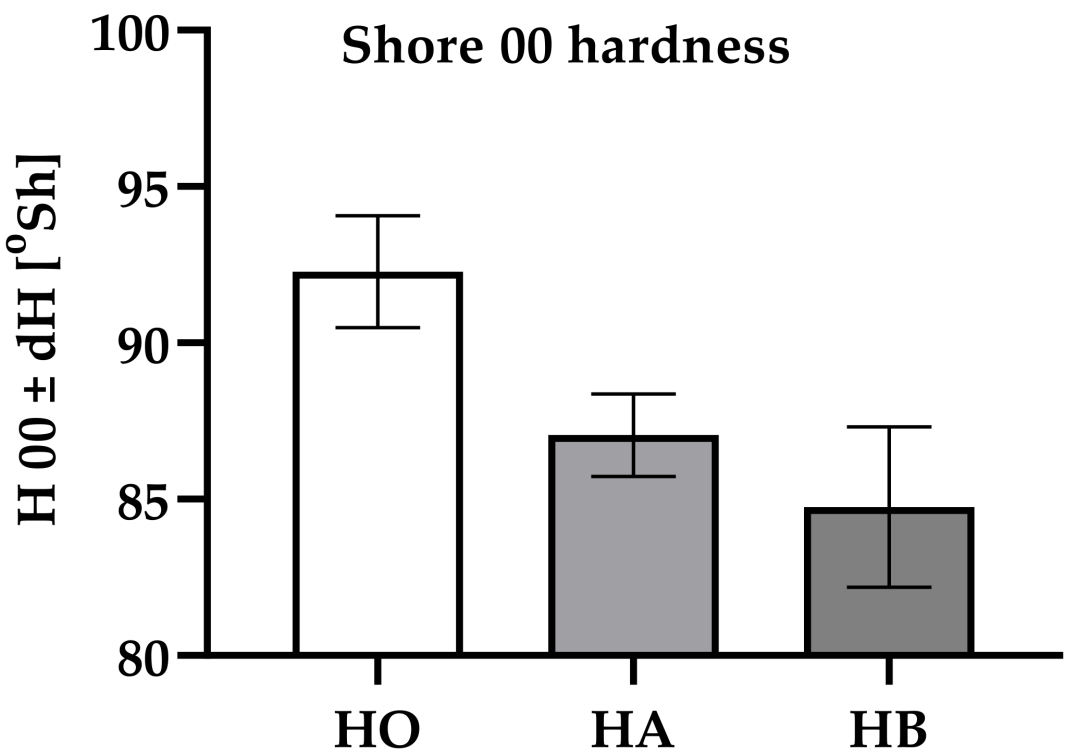

Figure 1. Hardness measurements of the composites.

\subsubsection{Breaking Strength}

A strength device (Zwick 1435, Zwick/Roell, Radeberg, Germany) was used to determine the static mechanical properties of the composites. The results are shown in Table 2 together with the standard deviations. 
Table 2. Results of mechanical measurements.

\begin{tabular}{ccc}
\hline \multirow{2}{*}{ Compositions } & \multicolumn{2}{c}{ Parameters } \\
\cline { 2 - 3 } & $\mathbf{T}_{\mathbf{S b}}[\mathbf{M P a}]$ & $\mathbf{E b}[\%]$ \\
\hline HO & $3.11 \pm 0.51$ & $8.22 \pm 2.38$ \\
HA & $0.71 \pm 0.10$ & $97.96 \pm 10.58$ \\
HB & $0.48 \pm 0.12$ & $6.12 \pm 3.98$ \\
\hline
\end{tabular}

Legend: $\mathrm{TS}_{\mathrm{b}}$-tensile strength in MP and $\mathrm{E}_{\mathrm{b}}$-relative elongation at break in $\%$.

The composite synthesized with the addition of acetic acid at a concentration of $0.5 \mathrm{M}$ (H0) showed the highest mechanical strength (Figure 2). This. This value was four times higher than the that for the HA composite and six-times higher than the value for the HB composite. The mechanical properties depended on the structure of the polymer. The large increase in mechanical strength may be related to intramolecular interactions in the H0 sample-for example, the formation of hydrogen bonds due to the action of hydrogen derived from acid, as was observed by infrared analysis (Figure 3).

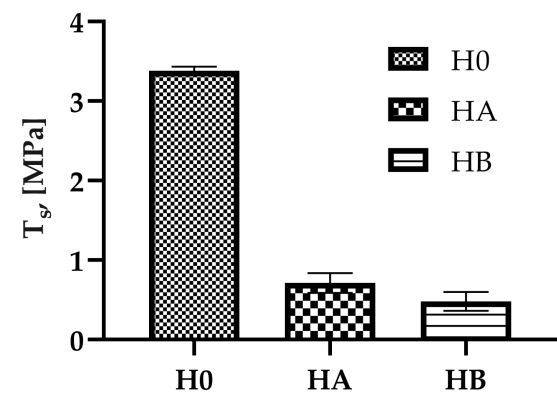

(a)

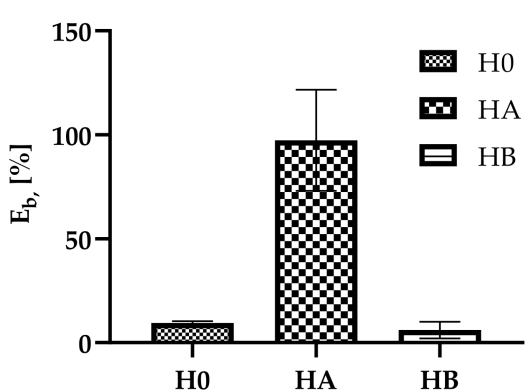

(b)

Figure 2. Tensile strength (a) and elongation at break (b) for H0, HA, and HB.

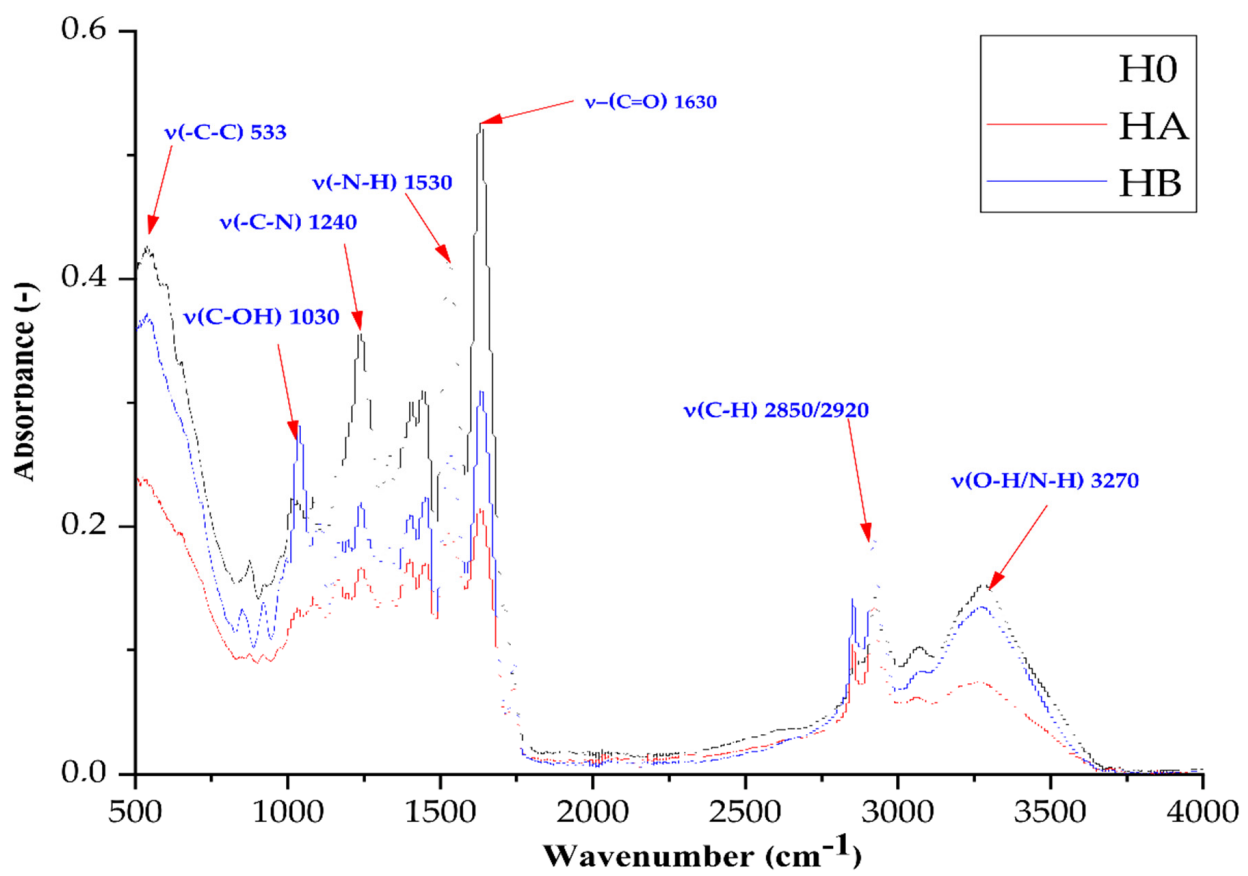

Figure 3. FTIR spectra of polymer composites. The black line represents the H0 composite, the red line represents the HA composite, and the blue line represents the HB composite. 
The HA composite showed the highest tensile strength. This may have been due to the much greater length of the macromolecule chains in the main chain (Figure 4c).

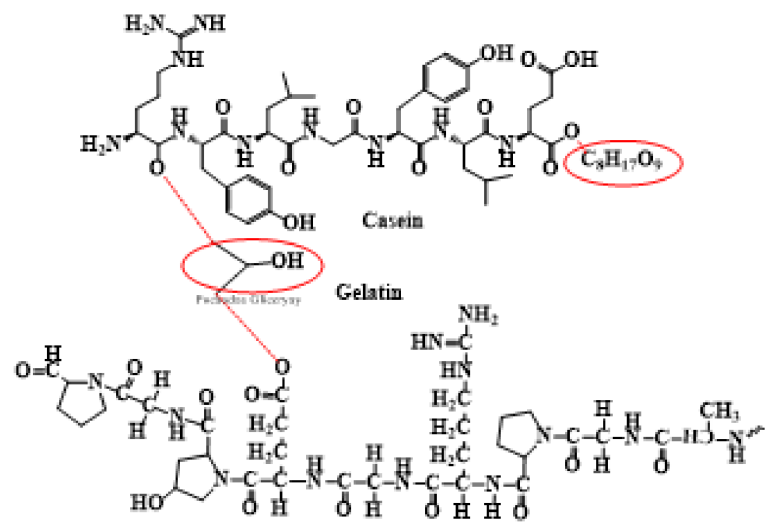

(a)

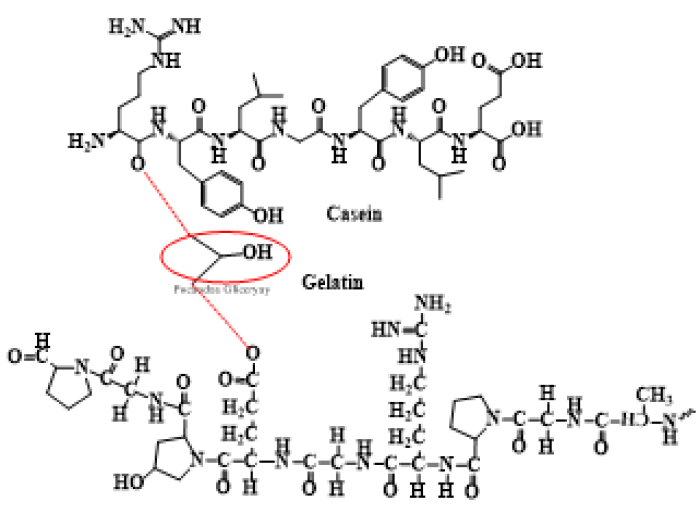

(c)

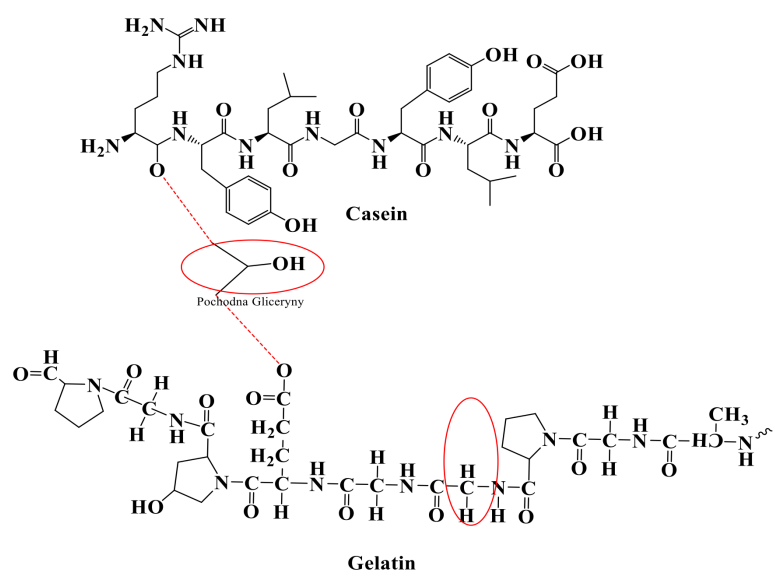

(e)

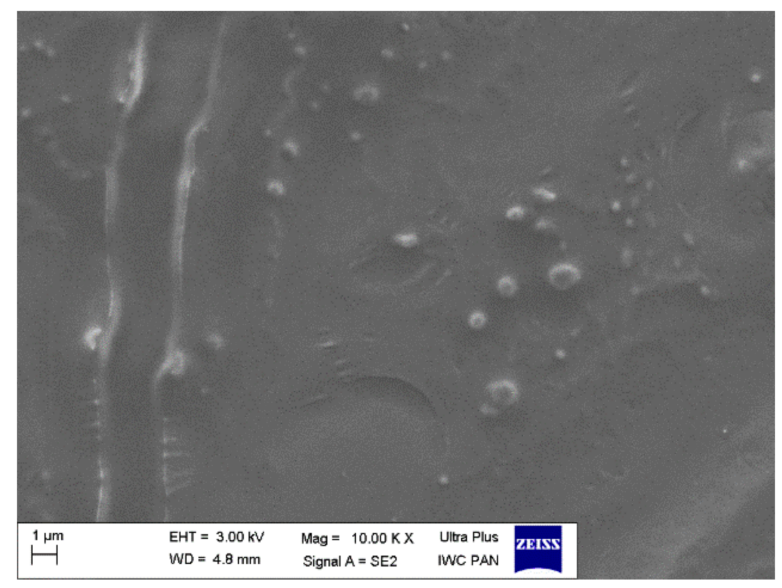

(b)

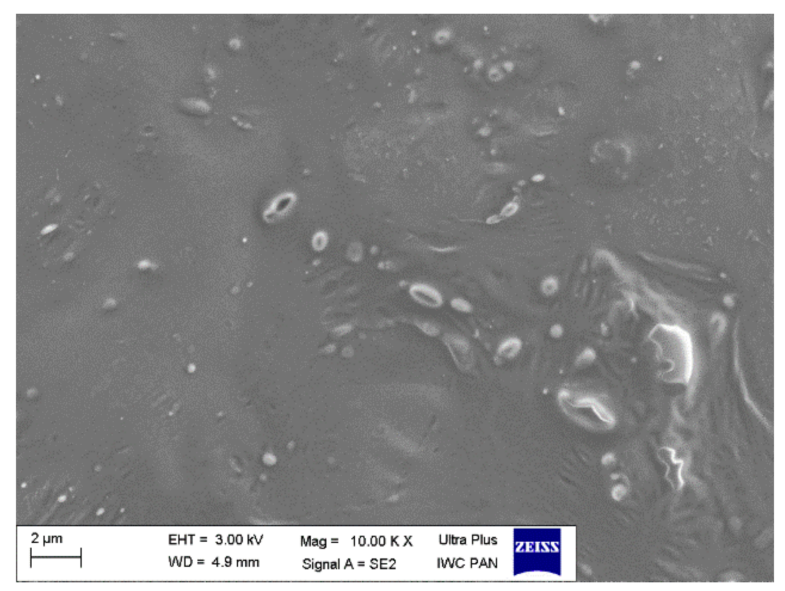

(d)

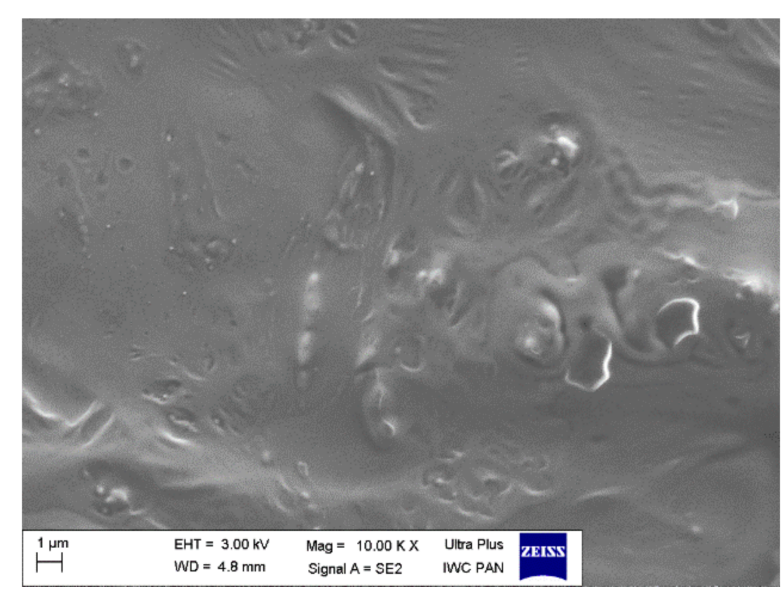

(f)

Figure 4. The probable mechanism of interaction (a,c,e) for composites H0, HA, HB and. SEM pictures (b,d,f) of H0, HA, HB films, mag. 10,000×.

\subsubsection{Spectroscopic Analysis}

The spectra show a large proportion of $-\mathrm{OH} / \mathrm{NH}\left(3270 \mathrm{~cm}^{-1}\right),-\mathrm{CH}\left(2850-2920 \mathrm{~cm}^{-1}\right)$, [39], and COO- $\left(1680 \mathrm{~cm}^{-1}\right)$ groups (Figure 3$)$. Aromatic bonds derived from casein are also 
visible $\left(920 \mathrm{~cm}^{-1}\right)$, as are primary and secondary proteins $\left(1240-1530 \mathrm{~cm}^{-1}\right)$ [39]. The shift of the amide bands towards their lower intensity may mean a reduction in the energy of the amine bonds and also indicates the enhancement of the interactions between gelatin and other components [40].

The main difference in the spectra of the obtained composites is the appearance or disappearance of peaks in the $800-950 \mathrm{~cm}^{-1}$ range. In the case of composite $\mathrm{H} 0$, a peak appears at the wave number of $875 \mathrm{~cm}^{-1}$. A similar peak was observed in the spectra of the HA composite, but not for the HB samples. This peak corresponds to the long [40] chain $-\mathrm{C}_{3} \mathrm{H}_{6}$.

The $\mathrm{HO}$ composite has a peak corresponding to $\mathrm{HCO}$ bonds $\left(943 \mathrm{~cm}^{-1}\right)$ [39]. The HB samples are distinguished by the appearance of a large amount of $\mathrm{CH}_{2}-\mathrm{CH}_{2}-\left(849 \mathrm{~cm}^{-1}\right)$. This bond may have arisen as a result of the main chain branches breaking during the operation of the base.

Possible schemes of the reaction mechanisms are presented in Section 2.1.4.

\subsubsection{Microscopic Research (SEM and TEM) and Reaction Mechanisms}

Pictures taken with a scanning electron microscope (SEM) showed the structures of the composites (Figure $4 \mathrm{~b}, \mathrm{~d}, \mathrm{f}$ ). Figure $4 \mathrm{~b}$ shows minor imperfections in the structure of the $\mathrm{HO}$ composite, which may be the result of undissolved casein agglomerates. The structure of the HA composite (Figure 4d) shows large imperfections, in the form of air bubbles and undissolved substrates. The structure of the HB composite (Figure 4f) shows small imperfections, which are more numerous than those seen in the picture of the $\mathrm{HO}$ composite (Figure 4b).All three composites were translucent. However, most likely due to their non-cross-linked substrates, due to the $\mathrm{pH}$ of the solutions during their synthesis, HA and $\mathrm{HB}$ were less transparent than the $\mathrm{HO}$ composite.

Figure $4 \mathrm{a}, \mathrm{c}$, and e show the predicted structures and mechanisms of the interactions between the individual components of each composite. The H0 composite shown in Figure $4 \mathrm{~b}$ (SEM) together with the proposed fragment of the structure shown in Figure $4 \mathrm{a}$, was the best in terms of mechanical properties. FTIR spectroscopy showed that there were long $\mathrm{C}_{8} \mathrm{H}_{17} \mathrm{O}_{9}$ bonds in the backbone lattice. Therefore, the $\mathrm{H} 0$ composite had a better produced polymer network in terms of mechanical parameters. Moreover, with the help of glycerin, carboxylic bonds formed in gelatin between the casein and gelatin, and an ether bond formed in the casein. The HA composite shown in Figure $4 \mathrm{~d}$ with the structure in Figure $4 \mathrm{c}$ was weaker in terms of mechanical properties, but more flexible. This composite also interacted with glycerin. However, it did not have an additional chain like the H0 composite, most likely due to the unstable lattice, which would explain its behavior. The $\mathrm{HB}$ composite shown in Figure $4 \mathrm{f}$ with the structure in Figure 4e was the weakest of the composites. This was probably due to the reorganization of the chains derived from gelatin during chemical modifications, as well as changes in the structure of the hydrocarbon chains of the $-\mathrm{CH}_{2}$ groups. Because of the lack of branches that would allow the polymer to flow, the composite stiffened and its properties deteriorated [41-43].

Analysis with Transmission Electron Microscope was carried out to determine the chemical composition of the obtained materials. Figure 5 shows graphs of different elements content in a samples H0, HA, and HB (Figure 5a-c). All three matrices are similar in chemical composition where majority of atoms consist of carbon (65-73\%) and oxygen (19-32\%). It is only logical that these atoms have definite majority than others hence the presence of aromatic groups from casein or aliphatic chains in gelatin. The presence of other atoms: chlorine $(0.2-4 \%)$, sodium $(0.2-1 \%)$, potassium $(0.05-0.11 \%)$, nitrogen $(0-6 \%)$, phosphorus $(0.02-0.06 \%)$, sulfur $(0.06-0.11 \%)$, and calcium $(0-0.11 \%)$ depends on the kind of skin used in the synthesis, level of preparation of said skin, source, the diet of the animal it came from, etc. [44-46]. 


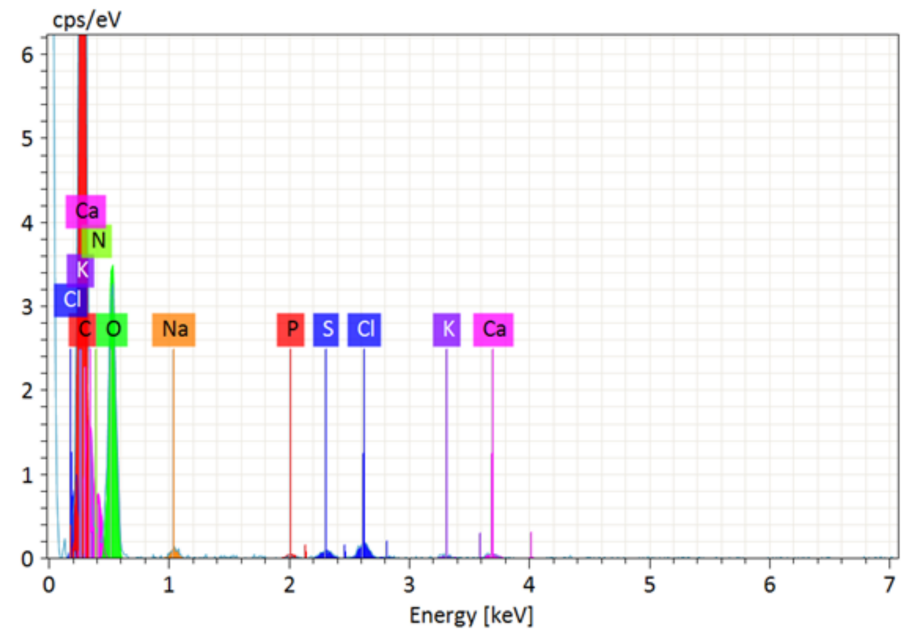

(a)

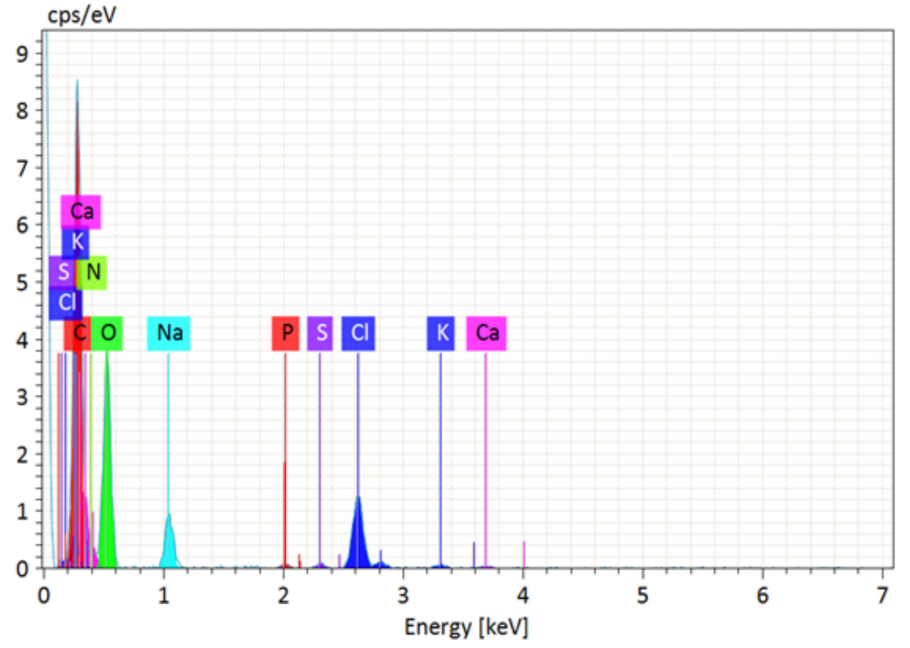

(b)

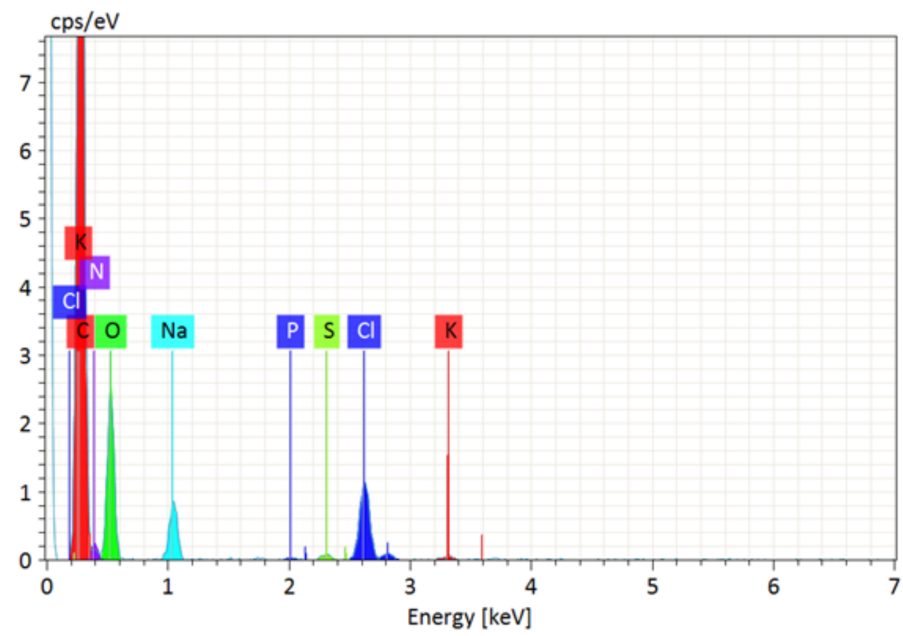

(c)

Figure 5. TEM analysis of the composites to determine their chemical composition: (a) graph depicting data for composite $\mathrm{H0}$; (b) graph depicting data for composite HA; (c) graph depicting data for composite HB. 


\subsubsection{DSC and TGA Analysis}

The results of differential scanning calorimetry (DSC) show that the sample of HA synthesized with the addition of $\mathrm{NaOH}$ had the highest value for glass transition, while the lowest value was for the sample synthesized with acetic acid H (Table 3; Figure 6). The difference may be due to the lower dissolution of casein, which is a natural flame retardant. This conclusion is supported by the results for the specific enthalpy of fusion, which was the lowest for the HA synthesized with the addition of $\mathrm{NaOH}$, indicating a worse distribution of the additive in the sample. The specific enthalpy of melting was the highest for sample $\mathrm{H} 0$, which proves that the components were well mixed. These results are supported by the SEM photos in Figure 4. Different $\mathrm{Tg}$ values determined by different authors for biopolymers such as gelatin, starch, etc. $[47,48]$ result not only from different processing conditions of the samples before the analysis, i.e., different water content [49], but also from different content of amino acids: hydroxyproline, proline, etc. resulting from the different histological origins of the protein source.

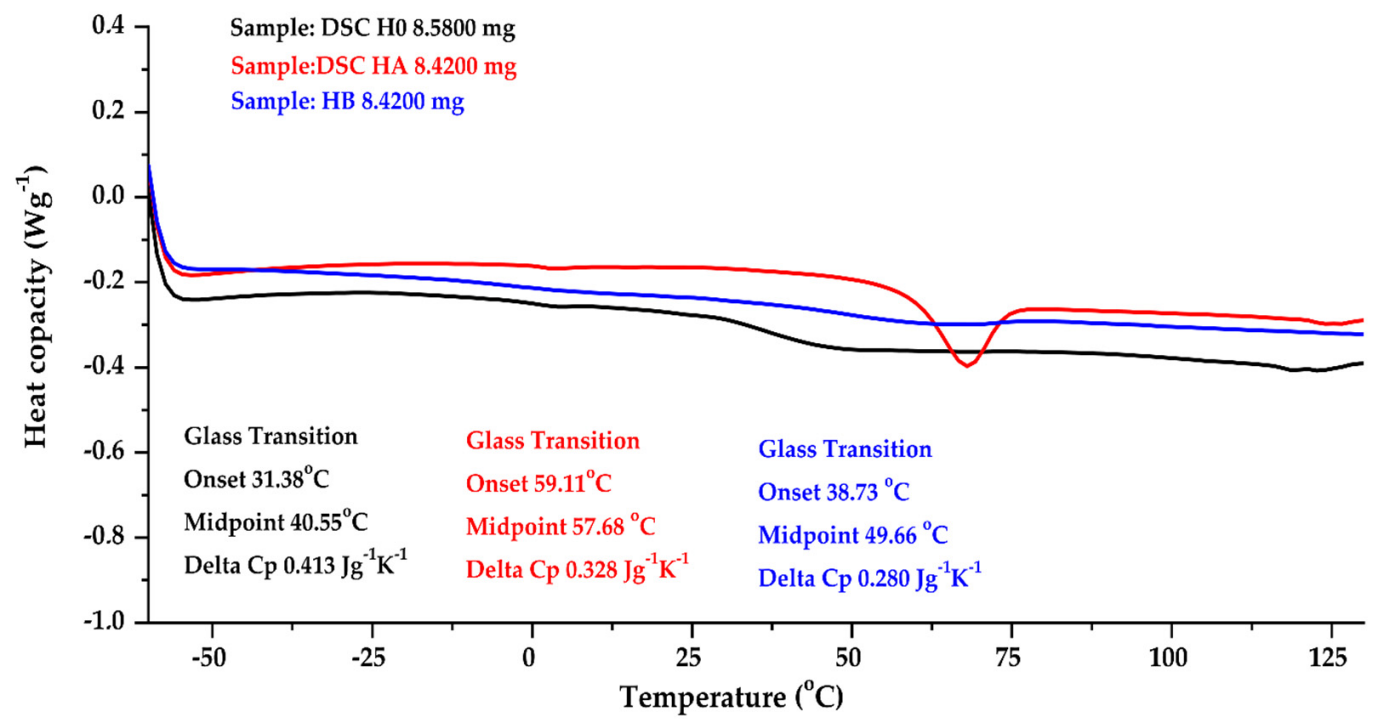

(a)

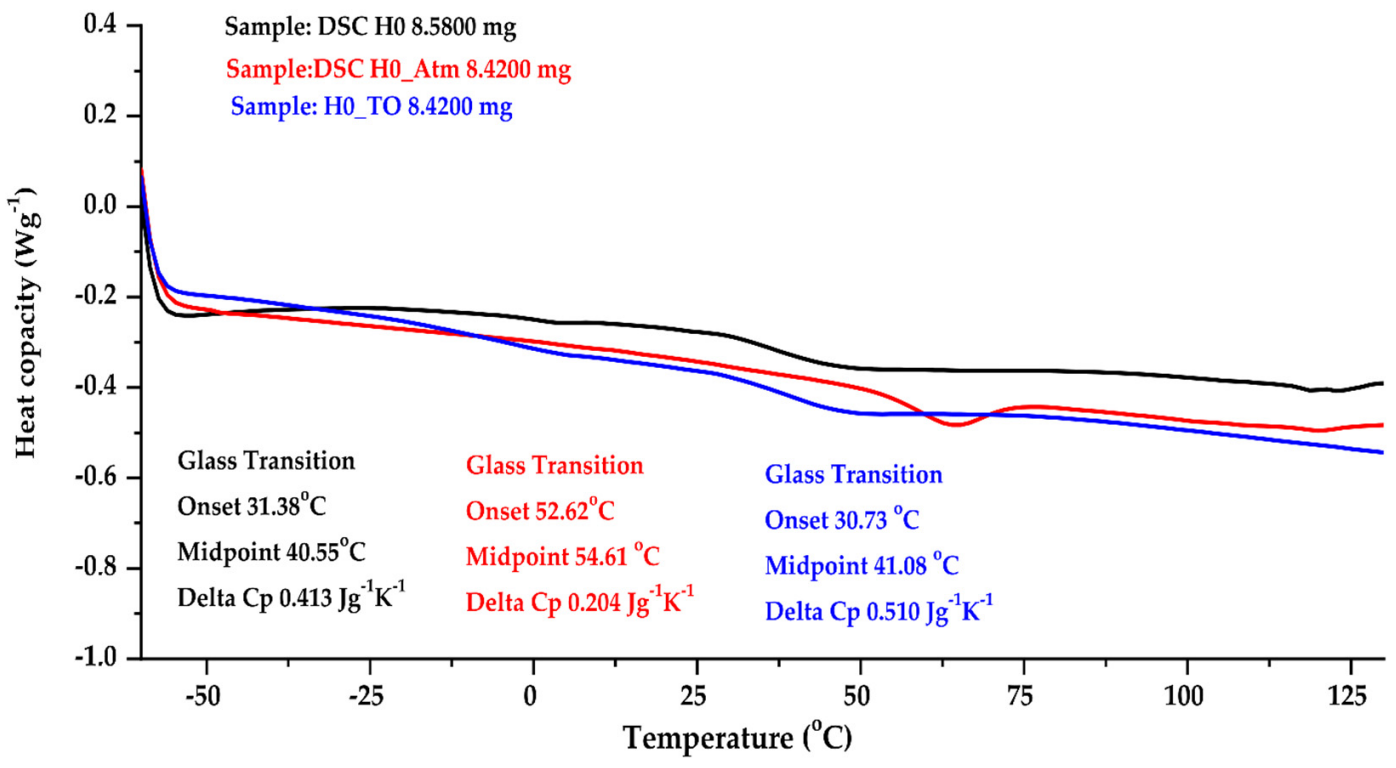

(b)

Figure 6. Cont. 


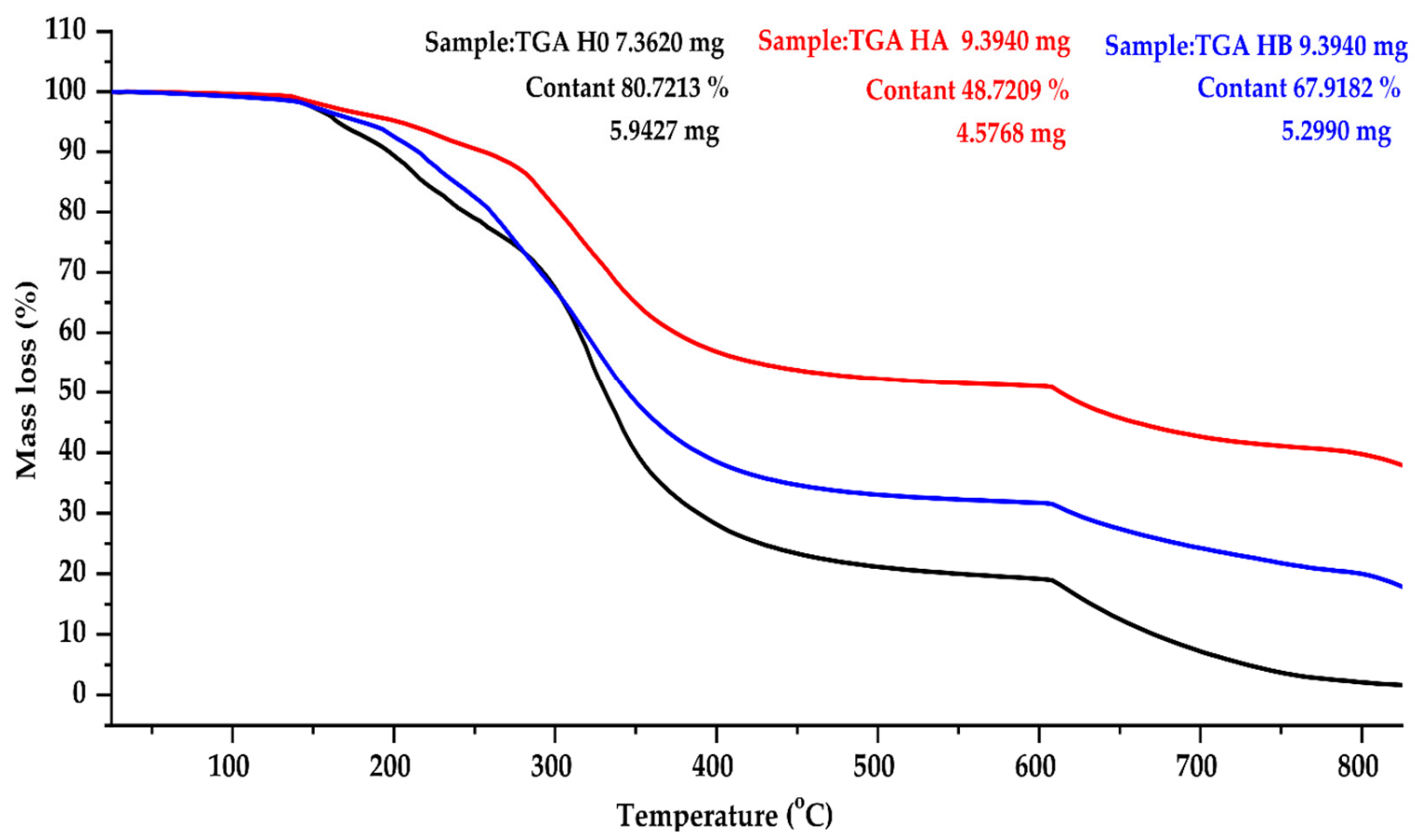

(c)

Figure 6. Results of DSC (a) and (b) and TGA (c) for the composites: H0 (black line), HA (red line), HB (blue line).

Table 3. Influence of collagen-gelatin composites on the thermal properties of $\mathrm{HO}, \mathrm{HA}$, and HB.

\begin{tabular}{cccc}
\hline Composites & $\mathbf{T g}\left[{ }^{\circ} \mathbf{C}\right]$ (ONSET) & $\operatorname{Tg}\left[{ }^{\circ} \mathrm{C}\right]$ (MIDPOINT) & $\Delta \mathbf{C p ~}[\mathbf{J} / \mathbf{g} \cdot \mathbf{K}]$ \\
\hline HO & 31.4 & 40.6 & 0.413 \\
HA & 52.6 & 54.6 & 0.204 \\
HB & 38.7 & 49.7 & 0.280 \\
\hline
\end{tabular}

Legend: $\mathrm{Tg}$-glass transition temperature ${ }^{\circ} \mathrm{C} ; \Delta \mathrm{Cp}$-heat capacity $\mathrm{J} / \mathrm{g} \cdot \mathrm{K}$.

\subsubsection{Analysis of the Contact Angle and SFE (Surface Free Energy)}

Table 4 summarizes the results of analysis of the contact angles of the H0, HA, and HB composites, proving their hydrophilicity. The reason for their hydrophilicity is the water contained in their network and the -OH groups, which are visible in the FTIR analysis. The angles of the non-polar liquid are in the result group $<90^{\circ}$, which means that the composite atoms on the surface also attract atoms from non-polar liquids, although less so than in the case of a polar liquid.

Table 4. Contact angles of the tested films for water, diiodomethane, and ethylene glycol.

\begin{tabular}{cccc}
\hline Composites & $\boldsymbol{\Theta}_{\text {water }}\left(^{\circ}\right)$ & $\boldsymbol{\Theta}_{\text {diiodomethane }}\left(^{\circ}\right)$ & $\boldsymbol{\Theta}_{\text {ethylene glycol }}\left(^{\circ}\right)$ \\
\hline HO & $43 \pm 4$ & $29 \pm 2$ & $49 \pm 1$ \\
HA & $24 \pm 2$ & $31 \pm 4$ & $50 \pm 3$ \\
HB & $27 \pm 1$ & $29 \pm 4$ & $44 \pm 5$ \\
\hline
\end{tabular}

Surface free energy (SFE) describes the surface tension of a solid, which arises as a result of molecular interactions between the body and air. The HB composite was characterized by the highest SFE (Table 5; Figure 7). This higher value is probably indicative of it having good wettability with any liquid. 
Table 5. Surface energies of the composites.

\begin{tabular}{cccc}
\hline Composites & $\begin{array}{c}\text { Dispersive Component } \\
{[\mathbf{m N} / \mathbf{m}]}\end{array}$ & $\begin{array}{c}\text { Polar Component } \\
{[\mathbf{m N} / \mathbf{m}]}\end{array}$ & $\begin{array}{c}\text { Surface Energy } \\
{[\mathbf{m N} / \mathbf{m}]}\end{array}$ \\
\hline HO & $40 \pm 1$ & $4 \pm 1$ & $43 \pm 1$ \\
HA & $24 \pm 2$ & $36 \pm 2$ & $60 \pm 3$ \\
HB & $26 \pm 2$ & $39 \pm 2$ & $64 \pm 3$ \\
\hline
\end{tabular}

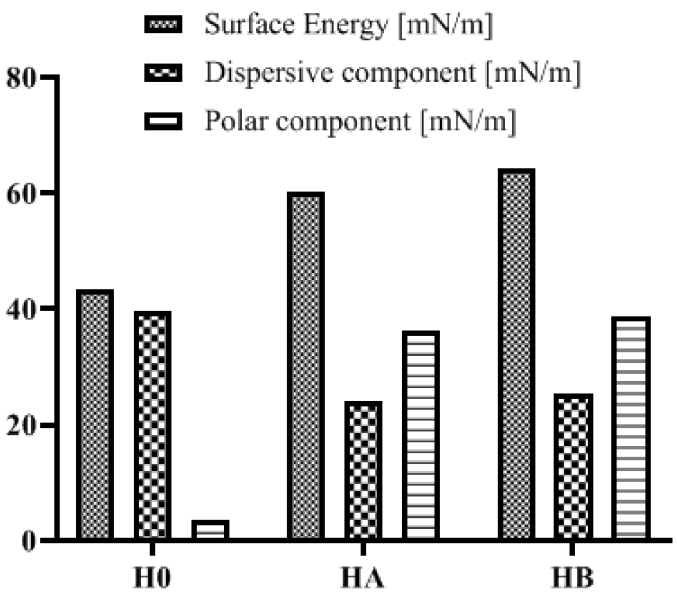

Figure 7. Comparison of surface energies as well as dispersive and polar components of the composites.

\subsubsection{Measurement of Equilibrium Swelling}

Equilibrium swelling $\left(Q_{w}\right)$ and the degree of cross-linking $\left(\alpha_{c}\right)$ were determined to investigate the water barrier for the absorption of the composites (Table 6).

Table 6. Equilibrium swelling $\left(Q_{w}\right)$ and the degree of cross-linking $\left(\alpha_{c}\right)$.

\begin{tabular}{ccc}
\hline Composition & $Q_{w}(-)$ & $\alpha_{c}(-)$ \\
\hline H0 & $0.0049 \pm 0.0014$ & $220 \pm 72$ \\
HA & $0.0161 \pm 0.0052$ & $67 \pm 24$ \\
HB & $0.0267 \pm 0.0098$ & $41 \pm 15$ \\
\hline
\end{tabular}

The highest degree of cross-linking was noted for the H0 composite. A durable network was produced during the synthesis of $\mathrm{H} 0$, due to the acidic $\mathrm{pH}$ and also by the use of an organic acid. The degradation of the collagen was also not as drastic as in the case of the base. From the FTIR spectra, it appears that the acidic $\mathrm{pH}$ enables the extension and/or modification of the main chain, which is later noticeable in the mechanical results. However, due to their similar processes of synthesis, there is only a small difference between the degree of cross-linking in the HA and HB composites.

\subsubsection{Determining the Susceptibility of the Composites to Biodegradation}

To determine the biodegradability of the composites, spatula-shaped samples were placed in containers and covered with a layer of universal primer ( $\mathrm{pH}$ 6.0-7.0). Measurements were made in accordance with the PN-EN ISO 846 standard. The containers were placed in a climatic chamber with a temperature of $30^{\circ} \mathrm{C}$ and a humidity of WWP $80 \%$. The measurement period was 30 days. After 30 days, the samples had completely decomposed. We concluded that the composites were characterized as well biodegradable. $90 \%$ of the material degraded, under conditions determined by the standard, throughout 7 days which is true for those type of materials in comparison with literature. [50]

Thermo-oxidative aging was carried out in accordance with the PN-821C-04216 standard. Paddle-shaped samples were placed in a circulating air dryer for seven days at $70{ }^{\circ} \mathrm{C}$. 
Atmospheric aging samples were left exposed to air and sunlight in the laboratory at $22-25{ }^{\circ} \mathrm{C}$ with varying humidity for 180 days. They were then subjected to further tests, to compare the changes occurring in the material under room conditions.

Due to the low mechanical strength and brittleness of the HA and HB compositions after thermo-oxidative aging, we decided to focus our further investigations on the best H0 material.

\subsection{Characteristics of Composites after Aging Processes}

\subsubsection{FTIR after Aging}

Fourier transform (FTIR) infrared spectroscopy was performed on the H0 samples after thermo-oxidative and atmospheric aging, as shown in Figure 8.

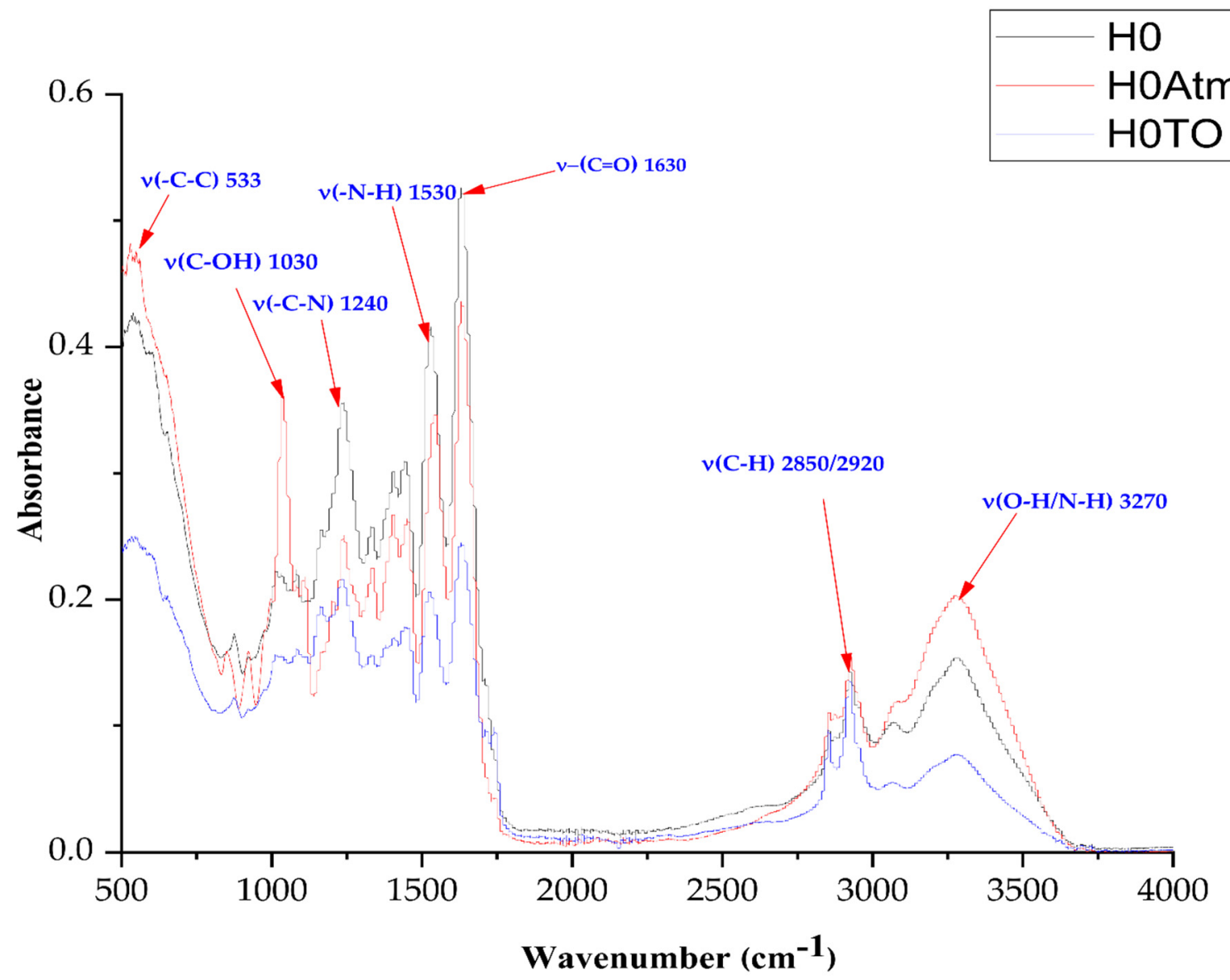

Figure 8. FTIR plot for films before H0 aging, after thermo-oxidative aging (H0_TO), and after atmospheric aging (H0_Atm).

In the H0_Atm samples after atmospheric aging, compared to other samples a peak appeared corresponding to the wavenumber of $1030 \mathrm{~cm}^{-1}$, which includes $\mathrm{C}-\mathrm{OH}$ bonds. The peak at $1165 \mathrm{~cm}^{-1}$ disappeared $[32,33,47]$, which indicates a lower effect of $-\mathrm{CH}_{2}-\mathrm{CH}_{2}-$ bonds. These results may indicate that the double bonds in the chain (e.g., in the gelatin chain) were broken during atmospheric aging and that the $\mathrm{OH}$ groups were combined in these places, as a result of the action of water in the air.

In the samples after thermo-oxidative aging, the peak disappearance was observed at the wave number of $1328 \mathrm{~cm}^{-1}$, corresponding to the $\mathrm{OH}$ deformation vibration bands. This was probably due to the fact that crystalline and bound water evaporates as a result of the temperature during aging.

After degradation, the structure of the composite did not show any major changes, proving its stability. 
2.2.2. Influence of Aging on the Mechanical Properties of Samples

After thermo-oxidative and atmospheric aging, the composites were tested for their mechanical properties. Hardness was tested using the Shore method. The breaking strength (Ts) and the elongation at break $\left(\mathrm{E}_{\mathrm{b}}\right)$ were tested on a Zwick Roell device. The results are presented in Table 7.

Changes were noted in the mechanical properties of the samples before and after aging. The unaged $\mathrm{HO}$ specimen had the highest values for hardness and tensile strength, but the lowest elongation at break compared to aged H0_TO and HO_Atm. The reason for such changes under the influence of aging is the fact that the bonds in the material structure change, as evidenced by the FTIR spectrum. The disappearance of double bonds and the appearance of $-\mathrm{OH}$ groups causes the composite to plasticize and increase its flexibility, but deteriorates its mechanical properties.

Table 7. Mechanical results for degraded samples.

\begin{tabular}{cccc}
\hline Composite & $\mathbf{H}_{\mathbf{0 0}} \pm \mathbf{d H}\left[{ }^{\circ} \mathbf{S h}\right]$ & $\mathbf{T s}_{\mathbf{b}}[\mathbf{M P a}]$ & $\mathbf{E}_{\mathbf{b}}[\mathbf{\%}]$ \\
\hline H0 & $92.3 \pm 1.3$ & $3.11 \pm 0.51$ & $8.22 \pm 2.38$ \\
\hline H0_TO & $92.0 \pm 1.5$ & $2.73 \pm 0.12$ & $58.85 \pm 5.11$ \\
\hline H0_Atm & $44.2 \pm 1.8$ & $0.55 \pm 0.14$ & $79.81 \pm 3.15$ \\
\hline
\end{tabular}

\subsubsection{TGA and DSC Analysis after Degradation Processes}

To analyze the degradation of the $\mathrm{H} 0$ samples subjected to thermo-oxidative and atmospheric degradation, we conducted TGA analyses (Figure 9a) and DSC analysis (Figure $9 b, c$ and Table 8).

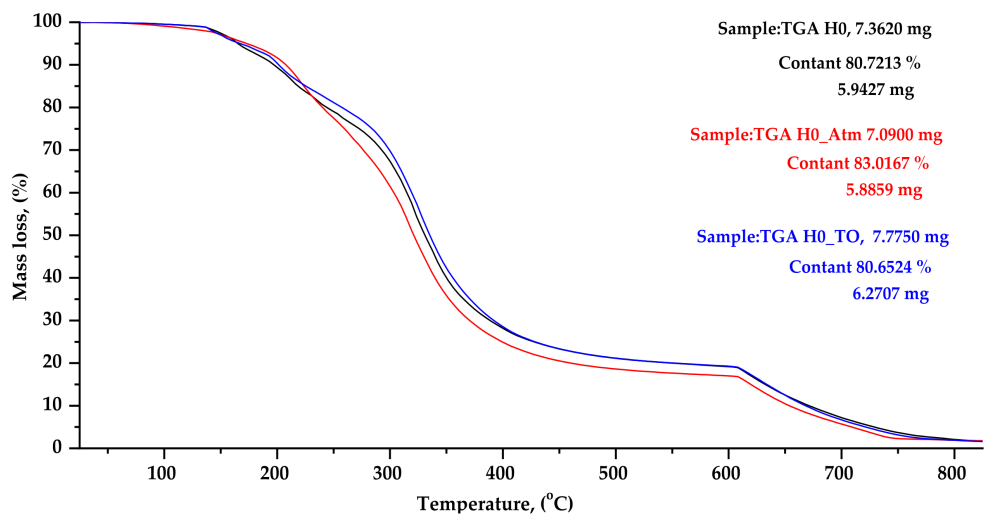

(a)

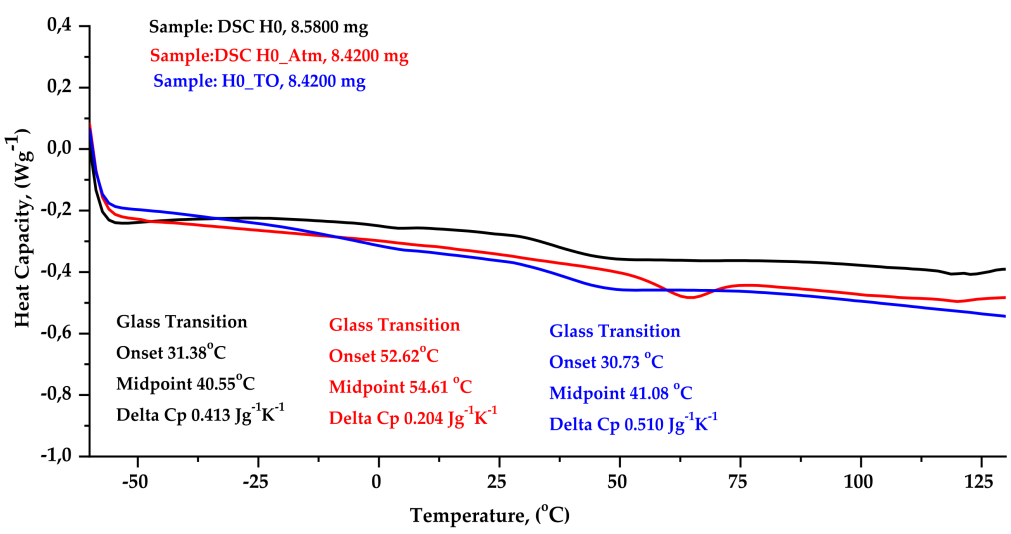

(b)

Figure 9. Cont. 


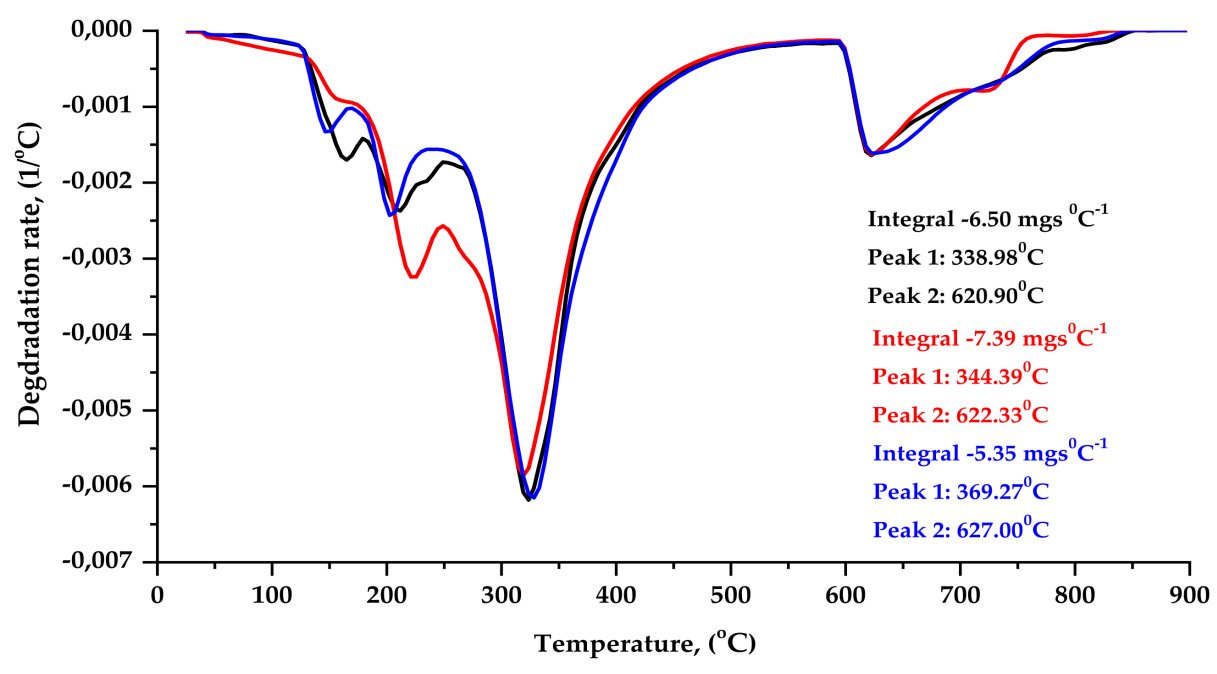

(c)

Figure 9. Thermogram of TGA (a) and DSC (b) and (c) for sample H0 before aging, after thermooxidative aging (H0_TO), and after atmospheric aging (H0_Atm).

Table 8. Thermal properties of $\mathrm{H} 0$ samples before and after degradation.

\begin{tabular}{cccc}
\hline Composites & $\operatorname{Tg}\left[{ }^{\circ} \mathbf{C}\right]$ (ONSET) & $\begin{array}{c}\mathbf{T g}\left[{ }^{\circ} \mathbf{C}\right] \\
\text { (MIDPOINT) }\end{array}$ & $\Delta \mathbf{C p ~}[\mathbf{J} / \mathbf{g} \cdot \mathbf{K}]$ \\
\hline H0 & 31.38 & 40.55 & 0.413 \\
H0_TO & 30.73 & 41.08 & 0.510 \\
H0_Atm & 52.62 & 54.61 & 0.204 \\
\hline
\end{tabular}

Figure 9a shows the results of TGA analysis of the H0 samples before and after aging. As can be seen from the thermogram, the initial weight loss occurs at $136{ }^{\circ} \mathrm{C}$. This is when the volatile substances present in the composites are formed. The second weight loss occurs at $608{ }^{\circ} \mathrm{C}$. At this point, the composite releases medium-volatility compounds.

Figure $9 \mathrm{~b}, \mathrm{c}$ shows the DSC $\mathrm{H} 0$ curves before and after aging. Atmospheric aging of the material shows an endothermic peak shifted to higher temperatures as a function of time. This was probably related to the enthalpy relaxation of the amorphous area.

As can be seen from the DSC results, the $\mathrm{H} 0$ composite shows different glass transition temperatures depending on the aging method. The sample after atmospheric aging showed the highest glass transition temperature. This may be related to the formation of -OH groups (Figure 9), which resulted in morphological changes such as secondary crystallization in the amorphous area of the material.

\subsubsection{Determination of Color Changes after Aging Processes}

The color changes in the composites before and after thermo-oxidative and atmospheric aging were tested in accordance with the PN-EN ISO 105-J01 standard, using a CIE Lab spectrophotometer. The results are given in Table 9 and presented for comparison in Figure 10. Composite $\mathrm{H} 0$ showed the strongest color change, which was visible with the naked eye. The color changes of the remaining composites were hardly noticeable or invisible to the human eye. The probable reason for the large color change of the $\mathrm{H} 0$ composite may be its stronger and more stable polymer network, which is degraded by the action of temperature and humidity, affecting the color of the composite. 
Table 9. Color changes of samples after aging.

\begin{tabular}{cc}
\hline \multicolumn{3}{c}{ Thermo-Oxidative Aging } \\
\hline Composition & $\mathbf{d E}^{*} \mathbf{a b}$ \\
\hline H0_TO & $54 \pm 1$ \\
HA_TO & $6 \pm 2$ \\
HB_TO & $15 \pm 1$ \\
\hline & Atmospheric aging \\
\hline Composition & $\mathbf{d E}^{*} \mathbf{a b}$ \\
\hline H0_Atm & $56 \pm 1$ \\
HA_Atm & $13 \pm 3$ \\
HB_Atm & $18 \pm 5$ \\
\hline
\end{tabular}

Legend: $\mathrm{dE}^{*} \mathrm{ab}-$ Color change factor

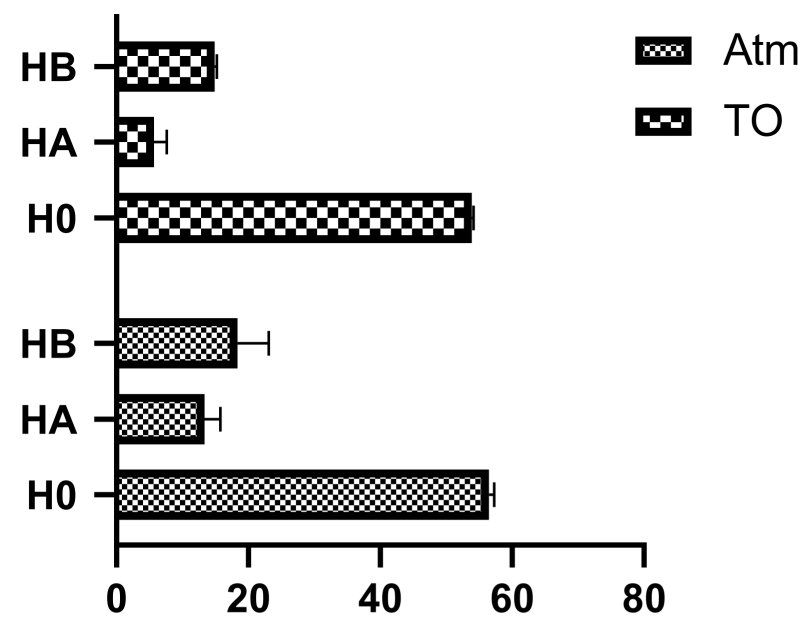

Figure 10. Comparison of color changes after aging of the composites.

\section{Materials and Methods}

\subsection{Research Facilities}

Frozen pig skin was obtained from "WĘDLINKA Sp. z o.o." (Wieruszów, Poland). The skin was cleaned under water, then the fat from the inner skin was scraped off. A skin $0.3-0.5 \mathrm{~cm}$ thick was obtained, then the skin was cut into $1 \mathrm{~cm} \times 1 \mathrm{~cm}$ strips. FoodCare gelatin (p.a., Mw 30 kDa, pH 4-8, Bloom 200, FoodCare Sp.z. Oo, Zabierzów, Poland) and glycerin (p.a., Mw $92 \mathrm{kDa}$; pH 5.5-8; relative density $1.26 \mathrm{~g} / \mathrm{cm}^{3}$, flashpoint $160{ }^{\circ} \mathrm{C}$, CHEMPUR, Piekary Ślaskie, Poland) were used to create the composite. Casein (pa, Mw $75 \mathrm{kDa}, \geq 95 \%$ alkali soluble, bulk density $450 \mathrm{~kg} / \mathrm{m}^{3}$, water solubility $20.1 \mathrm{~g} / \mathrm{L}$, SigmaAldrich Sp. z o. o., Poznań, Poland), proteolytic enzyme NUE 12 MG (p.a. Colagenase activity $0.28 \mathrm{U} / \mathrm{mL}$, effective $\mathrm{pH}$ range 4-9, Novozymes, Krogshoejvej, Denmark), glacial acetic acid $99.5 \%$ (Freezing / melting point $16.7^{\circ} \mathrm{C}$, relative density $1.0446 \mathrm{~g} / \mathrm{cm}^{3}\left(25^{\circ} \mathrm{C}\right)$ viscosity 1.056 mPaxs $\left(25^{\circ} \mathrm{C}\right), \mathrm{CHEMPUR}$, Poland), and sodium hydroxide $(\mathrm{pH}>13$; relative $2.13 \mathrm{~g} / \mathrm{cm}^{3}$, Freezing/Melting point $32-34{ }^{\circ} \mathrm{C}, \mathrm{CHEMPUR}$, Piekary Ślaskie, Poland) were also added.

\subsection{Preparation of the Composites}

Components of the composites and the technical parameters of their preparation (i.e., temperature, time, and ratios) were selected to obtain the desired chemical modifications. The best compositions are presented in Table 10. The solutions were prepared by mixing the raw materials in appropriate proportions by weight. 
Table 10. Compositions of the matrixes in PBW.

\begin{tabular}{|c|c|c|c|c|c|c|c|c|}
\hline \multirow{2}{*}{ Composition } & \multicolumn{8}{|c|}{ Ingredients/PBW } \\
\hline & Skin & Gelatin & Casein & Glycerin & NUE 12 MG & Distilled Water & Acetic Acid 0.5 M & $\mathrm{NaOH} 0.5 \mathrm{M}$ \\
\hline $\mathrm{HO}$ & & & & & & 7.5 & 60 & - \\
\hline HA & 10 & 1 & 1 & 2 & 33 & - & - & 100 \\
\hline $\mathrm{HB}$ & & & & & & 3.75 & - & 100 \\
\hline
\end{tabular}

The previously washed, peeled off, and cut skin (about $10 \mathrm{~g}$ ) was immersed in the enzyme solution (NUE $12 \mathrm{MG} 33 \mathrm{~g}$ was dissolved in $7.5 \mathrm{~mL}$ of water). In the case of the HA and $\mathrm{HB}$ samples, $0.5 \mathrm{M}$ sodium hydroxide solution at $\mathrm{pH}$ 6-8 was also introduced into this solution. For the H0 composite, only the enzyme solution was introduced. The solutions with the skin were left at room temperature for $24 \mathrm{~h}$. The difference between samples HA and $\mathrm{HB}$ is that $\mathrm{HB}$ enzyme and sodium hydroxide solution ( $\mathrm{pH} 7$ ) with skin (solution $\mathrm{A}$ ) was prepared alongside with enzyme and sodium hydroxide solution $(\mathrm{pH} 6)$ with food gelatin, casein, and glycerin (solution B) and both solutions were left for $24 \mathrm{~h}$.

The enzyme solution was then transferred to a reaction flask equipped with a reflux condenser, a thermometer, and magnetic stirrers. After the preparation of the synthesis setup, designated additives were added accordingly:

- H0: 0.5M acetic acid, glycerin, casein, and food gelatin

- HA: $0.5 \mathrm{M}$ sodium hydroxide ( $\mathrm{pH} 7$ ), glycerin, casein, and food gelatin

- HB: Solution A was transferred to the reaction flask and to it solution B was added and mixed

The synthesis was carried out at the temperature of $75^{\circ} \mathrm{C}$ for $4 \mathrm{~h}$, while stirring with a magnetic stirrer (Figure 11). An exemplary reaction set is shown in Figure 11.

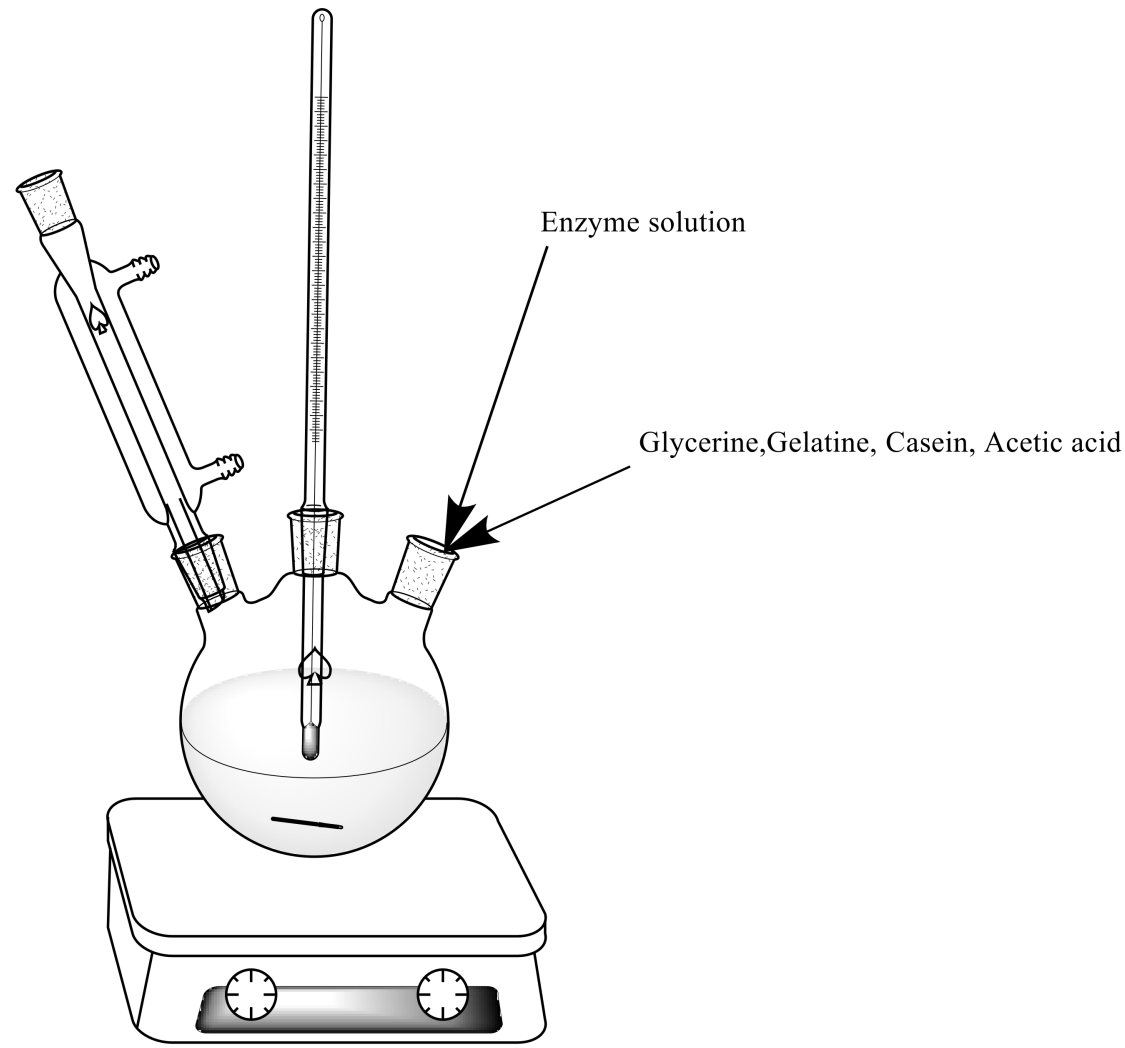

Figure 11. Exemplary scheme of composite synthesis. 
The products were thermostabilized (thermal chamber with air circulation Binder $\mathrm{GmbH}$, Germany) for $24 \mathrm{~h}$ at $80{ }^{\circ} \mathrm{C}$. The samples were formed on a hydraulic press into shapes corresponding to the measuring device (Skamet 54436, SKAMET, SkarżyskoKamienna, Poland) at a temperature of $105^{\circ} \mathrm{C}$ and a pressure of 120 bar (Figure 12).

H0

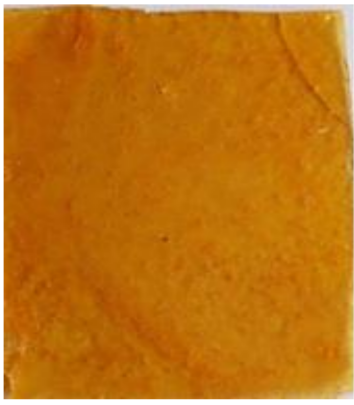

(a)
HA

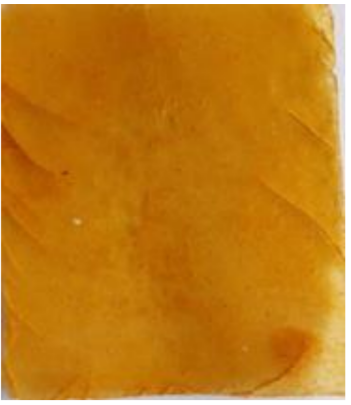

(b)
$\mathrm{HB}$

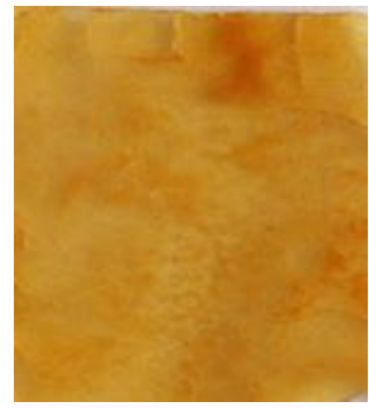

(c)

Figure 12. Pictures of compositions with fillers: H0 (a); HA (b); and HB (c); (private photo resources, CanonScan 4400F).

The samples obtained are $5 \times 5 \mathrm{~cm}$ in size and have a thickness of $1.50-1.60 \mathrm{~mm}$ Sample H0 (Figure 12a) formed a hard, brittle, translucent material. Sample HA (Figure 12b) formed a hard, translucent, but more flexible material compared to the H0 sample. The HB sample (Figure 12c) formed a hard and brittle material similar to the H0 sample.

\subsection{Research Techniques}

The composites were characterized using the following measuring devices: a Zwick 1435 testing machine (Zwick/Roell, Radeberg, Germany); a Shore hardness test device type 00 (Zwick/Roell, Herefordshire, Great Britain, pressure force $400 \mathrm{~g}$, indenter 3/32); a Nicolet 6700 spectrophotometer (Thermo Scientific, Waltham, MA, USA); an OCA 15EC goniometer (Dataphysics, Filderstadt, Germany); a DSC ${ }_{1}$ differential scanning calorimeter (Mettler Toledo, Netzsch, Switzerland), a TGA (Mettler Toledo, Netzsch, Switzerland). A UV-VIS CM-3600d spectrophotometer (Konica Minolta, London, UK) was used for scanning electron microscopy (SEM) to identify the structure of the composites. Photographs were taken using a CanonScan scanner (Canon Inc. Ōta, Tokyo). The HPP 108 climatic chamber (Memmert GmbH, Schwabach, Germany) was used to determine biodegradation.

The prepared biocomposites were subjected to mechanical analysis both before and after the thermo-oxidative aging processes. Measurements were made in accordance with PN ISO 37: 1998 (D1235 ASTM). The paddle-shaped specimens were stretched to determine the tensile strength $\left(\mathrm{T}_{\mathrm{Sb}}, \mathrm{MPa}\right)$ and the relative elongation at break $(\mathrm{Eb}, \%)$. The hardness of the samples was measured (ISO 7619-1 standard) with a Shore 00 digital hardness tester on the 00 scale.

FTIR spectroscopy was used to identify vibrations characteristic for functional groups on the basis of changes that occurred in the tested biopolymers compared to the reference sample. Measurements were carried out in the radiation wavelength range of $4000-500 \mathrm{~cm}^{-1}$ with a resolution of $0.25 \mathrm{~cm}^{-1}$.

To determine the surface energy value for synthesized samples using the Owens, Wendt, Rabel, and Kaelble method. Measurements of the contact angle for composites were made with two liquids: polar (distilled water) and non-polar (diiodomethane). The deposition mechanism of the surface layer indicates the morphology of the layer itself and 
its electrical properties. The surface free energy was calculated using Equation (1), based on the surface energies of a polar and non-polar substance [51,52]:

$$
\gamma S=\gamma S_{p}+\gamma S_{d}
$$

Using the equation, the relationship (2) was derived, the polar component $\gamma_{S}^{\mathrm{p}}$ was determined, which corresponds to the sum of the forces of: hydrogen, acid-base and inductive interactions, and the dispersion component $\gamma_{\mathrm{S}}^{\mathrm{p}}$ is determined by the London forces:

$$
\frac{\gamma(1+\cos \theta)}{2}=\sqrt{\gamma_{\mathrm{S}}^{\mathrm{d}} \gamma_{\mathrm{L}}^{\mathrm{d}}}-\sqrt{\gamma_{\mathrm{S}}^{\mathrm{p}} \gamma_{\mathrm{L}}^{\mathrm{p}}} 2
$$

where: $\theta$ - contact angle of the tested surface by the measuring liquids $\left[{ }^{\circ}\right], \gamma \mathrm{L}$-surface free energy of the measuring liquid $\left[\mathrm{mJ} / \mathrm{m}^{2}\right], \gamma \mathrm{S}$ - surface free energy of a solid $\left[\mathrm{mJ} / \mathrm{m}^{2}\right]$; $\gamma \mathrm{SL}$-surface free energy at the solid-liquid interface $\left[\mathrm{mJ} / \mathrm{m}^{2}\right]$.

The equilibrium swell value is related to the nature of the polymer-solvent relation and provides information on the nature of crosslinking and reinforcement.

Calculation of structural parameters of three-dimensional networks based on the results of equilibrium swelling measurements is based on the theoretical work of Florry and Rener [53]. When the polymeric three-dimensional network swells, the solvent penetrates into the macromolecule and the free energy changes as a result of mixing the polymer and solvent molecules. Dissolving the polymer chain is difficult through the chemical bonds that bind macromolecules together.

The measurement was made in accordance with the PN-ISO 1817: 2011/Ap1: 2002 standard. Three samples having weights in the range of 30-40 $\mathrm{mg}$ were cut from each composition. The samples were placed in water for $48 \mathrm{~h}$ at room temperature. After the samples were dried and the weight constant was obtained, further measurements were taken.

$$
Q_{w}=\frac{m_{s p}-m_{s}}{m_{s}}
$$

$m_{s p}$-weight of the swollen sample [mg]

$m_{s}-$ mass of the dried sample after swelling [mg]

$$
\alpha_{c}=\frac{1}{Q_{w}}
$$

Thermogravimetric analysis (TG) and differential scanning calorimetry (DSC) are methods of thermal analysis. TGA analysis-the change in sample weight as a function of temperature is recorded. This method of analysis is based on the observation of the mass of the test substance sample with changes in temperature. The results of the analysis are TG curves describing the dependence of the sample mass (or change in sample mass) on temperature or time [54].

The difference in the amount of heat required to raise the temperature of the sample and standard, measured as a function of temperature, was determined by Differential Scanning Calorimetry (DSC) [55]. DSC is used to measure heat power, allows for estimation of glass transition temperature (Tg) and determination of capacitance changes heat capacity $(\Delta \mathrm{Cp})$. The change in heat capacity at glass transition $\Delta \mathrm{Cp}$ can be defined as the amount of heat necessary to change the body temperature by the temperature unit per $1 \mathrm{~g}$ of the sample, expressed in $[\mathrm{J} / \mathrm{g} \cdot \mathrm{K}]$.

Thermo-oxidative aging was carried out in accordance with the PN-821C-04216 standard. Samples cut into the shape of a paddle were dried in a Binder dryer with circulating air for seven days at $70^{\circ} \mathrm{C}$. Biodegradation of the samples was carried out in accordance with the PN-EN ISO 846 standard. Paddle-shaped samples were cut from the composites, placed in containers with soil, then put into a Memmert climate chamber (Memmert GmbH, Schwabach, Germany) for 14 days at $30{ }^{\circ} \mathrm{C}$ with air humidity of $80 \%$. All three compositions of $\mathrm{HO}, \mathrm{HA}$, and $\mathrm{HB}$ were dissolved in soil after the study. Therefore, they were not 
subjected to further tests. Using the PN-EN ISO 105-J01 standard, the samples were tested for color changes on a UV-VIS CIE Lab color space spectrophotometer.

\section{Conclusions}

This work has presented the results of research on biopolymer composites based on animal-derived gelatin with the addition of casein, food gelatin, glycerin, cellulose acetate, chitosan, and agarose. The additives were selected for their cross-linking properties. Glycerin was added to assist with the production of a film. Food gelatin was also added to improve the mechanical properties of the material. Composite H0 was obtained by extracting gelatin from pig skin by an enzymatic reaction in acetic acid solution. It was the hardest of the tested composites. $\mathrm{H} 0$ also showed the best mechanical strength. These results indicate that $\mathrm{H} 0$ was a homogeneous material, in terms of additive dispersion. Infrared analysis showed a large proportion of the -OH $\left(2800-3500 \mathrm{~cm}^{-1}\right), \mathrm{NH}_{2}(3500-$ $\left.3300 \mathrm{~cm}^{-1}\right)$, and $\mathrm{CH}_{2}\left(3095-3050 \mathrm{~cm}^{-1}\right)$ groups, as well as many of the aromatic bonds $\left(3075-3030 \mathrm{~cm}^{-1}\right)$, were derived from casein. Primary and secondary proteins (1550$1650 \mathrm{~cm}^{-1}$ ), as well as tertiary proteins (approximately $1100 \mathrm{~cm}^{-1}$ ), were also visible, as they were in the other composites (HA and $\mathrm{HB}$ ). However, the share of the-OH group in the $\mathrm{H} 0$ composite was smaller than that in the HA and HB composites.

SEM pictures showed that the $\mathrm{H} 0$ sample had some imperfections, due to the casein being not fully dissolved in the solution. On the basis of infrared analysis, we concluded that $\mathrm{H} 0$ had the least branched and cross-linked structure of long polymer chains, and therefore it may be characterized as the least stable spatial network.

TGA and DSC analysis showed that all three compositions had a similar glass transition temperature. However, the $\mathrm{H} 0$ composite had twice the heat capacity. A contact angle test revealed that all three compositions were wettable by both polar and non-polar liquids. This means that they were also hydrophilic, which may limit their use in the packaging industry.

The HB composite had the highest free surface energy, and H0 the lowest. Equilibrium swelling showed that the $\mathrm{H} 0$ composite had the highest degree of cross-linking. Its strong network was created during the process of synthesis, thanks to the acidic environment. It was also influenced by the use of a weak organic acid, which did not completely degrade the helical collagen fibers, but led to loosening of the structure of polypeptide chains. This ensured their appropriate strength. In contrast, the $\mathrm{H} 0$ composite had the highest degree of cross-linking, due to the alkaline environment in which it was synthesized.

Due to their poor mechanical properties after aging, HA and HB were excluded from further testing. The reason for their advanced degree of degradation may be the use of a strong base, which broke the peptide bonds in the collagen and gelatin helices, hindering the formation of a stable polymer network.

The results of infrared spectroscopy showed slight changes in the absorption bands of the $\mathrm{H} 0$ composite, which means that it had a stable polymer network. There were, however, changes in the $-\mathrm{OH}$ bonds. Atmospheric aging indicated an increase in the presence of hydroxyl groups, associated with the absorption of water from the air. On the other hand, after thermo-oxidative aging the $-\mathrm{OH}$ groups disappeared, which means that most of the crystalline and structurally bound water evaporated under the influence of temperature.

In terms of mechanical properties, the aged $\mathrm{H} 0$ composite specimens had a higher percentage of elongation at break. The disappearance of $-\mathrm{CH}_{2}$ groups caused the composite to plasticize and increased its flexibility, at the expense of reducing its mechanical properties.

Thermogravimetric analysis (TGA) showed the presence of volatile and semi-volatile substances in the $\mathrm{H} 0$ composite, which were released during degradation at high temperatures. The results of DSC measurements showed a change in the glass transition temperature under the influence of atmospheric aging. Secondary crystallization in the amorphous space of the material may have occurred, due to the absorption of moisture from the air, leading to a decrease in the homogeneity of the material. 
Color changes were measured for all three compositions. Compared to HA and HB, the $\mathrm{HO}$ composite was characterized by a large change in color after both atmospheric and thermo-oxidative aging. This was due to the degradation of the more stable polymer network in the composite compared to the other samples, in which the main polymer chains were shorter.

These composites do not stray from the materials used in tissue engineering research. We suspect its potentiality in nanostructural growth as well as base for new biomimetic cement as bone replacement as well as biodegradable implantations for better biocompatibility $[38,44,45]$.

Author Contributions: Concept: M.P., S.S. and O.D.; methodology: S.S.; software: O.D.; validation: M.P., S.S. and R.A.; formal analysis: M.P.; investigation: S.S. and O.D.; resources: M.P.; data curation: M.P.; original draft: S.S.; editing: O.D.; review: M.P.; visualization: O.D. and S.S.; supervision: M.P.; project administration: S.S. and R.A. All authors have read and agreed to the published version of the manuscript.

Funding: The research was carried out within the statutory funds of Lodz University of Technology.

Conflicts of Interest: The authors declare no conflict of interest.

\section{References}

1. Francis, J.; Arun, K.; Navas, A.; Joseph, I. Biomedical Applications of Polymers. Curr. Trends Biomed. Eng. Biosci. 2018, 15, 44-45. [CrossRef]

2. Nicotra, F. Organic and Bio-Molecular Chemistry; Eolss Publishers Co. Ltd.: Paris, France, 2009; Volume I, 50p.

3. Chandrasekaran, C. Anticorrosive Rubber Lining: A Practical Guide for Plastics; Elsevier: Amsterdam, The Netherlands, 2017; 32p.

4. Bastioli, C. Handbook of Biodegradable Polymers; RAPRA Technology: Shawbury, UK, 2005; p. 183.

5. NPCS. Select $\mathcal{E}$ Start Your Own Industry, 4th ed.; NPCS: Delhi, India, 2012; 310p.

6. Targonska, A. Analiza Procedury Uzyskania Pozwolenia na Recykling Odpadów z Tworzyw Sztucznych, Zrównoważony Rozwój Wektorem na Drodze Doskonalenia Warsztatu Naukowca; Wydawnictwo Politechniki Ślaskiej: Gliwice, Poland, 2021.

7. Anawar, H.M.; Strezov, V. Abhilash. Sustainable and Economic Waste Management: Resource Recovery Techniques; CRC Press: New York, NY, USA, 2019.

8. Akelah, A. Functionalized Polymeric Materials in Agriculture and the Food Industry; Springer: Berlin, Germany, 2013; Volume 2, 72p.

9. Ogawa, Y. Research on recycle process and energy consumption about recycle of construction waste. J. Environ. Eng. Trans. AIJ 2006, 71, 604 .

10. Martinsen, T.H.; Vassnes, E. Waste tax in Norway. In Addressing the Economics of Waste, Proceedings of the Workshop on the Economic of Waste, Paris, France, 14-15 October 2003; OECD: Paris, France, 2004; p. 85. 85p.

11. Vikhareva, I. Ecotoxicity of the Adipate Plasticizers: Influence of the Structure of the Alcohol Substituent. Molecules 2021, 26, 4833. [CrossRef] [PubMed]

12. Vikhareva, I. Assessment of Ecotoxicity of Incinerated Sewage Sludge Ash (ISSA). Minerals 2021, 11, 849.

13. Katare, Y. Microplastics in Aquatic Environments: Sources, Ecotoxicity, Detection \& Remediation. Biointerface Res. Appl. Chem. 2021, 12, 3407-3428.

14. Ramires, P. Ecotoxicity of Triclosan in Soil: An Approach Using Different Species. Environ. Sci. Pollut. Res. 2021, 10, 41233-41241. [CrossRef]

15. Green, J. Statistical Analysis of Ecotoxicity Studies; Wiley: Hoboken, NJ, USA, 2018.

16. Bloom, A.D. Ecotoxicity and Human Health: A Biological Approach to Environmental Remediation; CRC Lewis Publishers: Cambridge, MA, USA, 1995; 192p.

17. Horst, B. Natural polymers: Biomaterials for skin scaffolds. In Biomaterials for Skin Repair and Regeneration; García-Gareta, E., Ed.; Woodhead Publishing: Sawston, UK, 2019; pp. 151-192.

18. National Academy of Sciences. National Academy Science Letters; National Academy of Sciences: Washington, DC, USA, 2019; Volume 29, 318p.

19. Roy, I. Polyhydroxyalkanoate (PHA) based Blends, Composites and Nanocomposites; RSC Green Chemistry: London, UK, 2006; Volume 30, 121p.

20. Joutey, N. Biodegradation: Involved Microorganisms and Genetically Engineered Microorganisms. In Biodegradation-Life of Science; InTech: Rijeka, Croatia, 2013; Chapter 11. [CrossRef]

21. Kuruvilla, J. Materials for Potential EMI Shielding Applications: Processing, Properties; Elsevier: Amsterdam, The Netherlands, 2019; 166p.

22. Ouellette, R.J.; Rawn, J.D. 1-structure and bonding in organic compounds. Organic Chemistry; Elsevier: Boston, MA, USA, 2014; pp. 1-39.

23. Sheikh, Z. Biodegradable Materials for Bone Repair and Tissue Engineering Applications. Materials 2015, 8, 5744-5794. [CrossRef] 
24. Kalia, S.; Averous, L. Biopolymers: Biomedical and Environmental Applications; John Wiley \& Sons: Hoboken, NJ, USA, 2011; Volume 70.

25. Murthy, N.; Wilson, S.; Sy, J.C. Biodegradation of polymers. In Polymer Science: A Comprehensive Reference; Elsevier: Amsterdam, The Netherlands, 2012; Volume 10, pp. 547-560.

26. Vroman, I. Biodegradable Polymers. Materials 2009, 2, 307-344. [CrossRef]

27. Biswal, T. Biopolymers for tissue engineering applications: A review. Mater. Today Proc. 2021, 41, 397-402. [CrossRef]

28. Encalada, K. An overview of starch-based biopolymers and their biodegradability. Cienc. Ing. 2018, 3, $245-258$.

29. Zhang, X. Chemical Modification of Gelatin by a Natural Phenolic Cross-linker, Tannic Acid. J. Agric. Food Chem. 2010, 58, 6809-6815. [CrossRef]

30. Prochon, B. Preparation and Characterization of New Environmentally Friendly Starch-Cellulose Materials Modified with Casein or Gelatin for Agricultural Applications. Materials 2019, 12, 1684. [CrossRef]

31. Djagny, K. Chemical Modification of Pigskin Gelatin: Factors Affecting the Esterification of Gelatin with Fatty Acid. J. Food Sci. 2001, 66, 1326-1330. [CrossRef]

32. Kosaraju, S. Naturally crosslinked gelatin gels with modified material properties. Food Res. Int. 2010, 43, 2385-2389. [CrossRef]

33. Kozlov, P. The structure and properties of solid gelatin and the principles of their modification. Polymer 1983, 24, 651-666. [CrossRef]

34. Andersen, L.P. Method for Dehairing of Hides or Skins by Means of eEnzymes. Patent No. US5834299A, 10 November 1998. Available online: https:/ / patents.google.com/patent/US5834299A/en (accessed on 20 November 2021).

35. Herve, Y. The effect of modified keratin on the thermal propertiesof a cellulosic-elastomeric material. J. Therm. Anal. Calorim. 2016, 125, 1151-1160.

36. Buie, T. Gelatin Matrices for Growth Factor Sequestration. Trends Biotechnol. 2020, 38, 546-557. [CrossRef]

37. Fang, X. Biomimetic gelatin methacrylamide hydrogel scaffolds for bone tissue engineering. J. Mater. Chem. 2016, 6, 1070-1080. [CrossRef]

38. Bigi, A. A Biomimetic Gelatin-Calcium Phosphate Bone Cement. Int. J. Artif. Organs 2004, 27, 664-673. [CrossRef]

39. Hadjiivanov, I. Power of Infrared and Raman Spectroscopies to Characterize Metal-Organic Frameworks and Investigate Their Interaction with Guest Molecules. Chem. Rev. 2021, 121, 1286-1424. [CrossRef]

40. Zhang, N. Phase composition and interface from starch-gelatin blends studio by synchrotron FTIR micro-spectroscopy. Carbohydr. Polym. 2013, 95, 649-653. [CrossRef]

41. Li, M. Electrospinning polyaniline-contained gelatin nanofibers for tissue engineering applications. Biomaterials 2006, 27, 2705-2715. [CrossRef]

42. Kanmani, P. Physicochemical properties of gelatin/silver nanoparticle antimicrobial composite films. Food Chem. 2014, 148, 162-169. [CrossRef]

43. Van Vlierberghe, S. Porous Gelatin Hydrogels: Cryogenic Formation and Structure Analysis. Biomacromolecules 2007, 8, $331-337$. [CrossRef]

44. Neupane, M.P. Synthesis of gelatin-capped gold nanoparticles with variable gelatin concentration. J. Nanopart. Res. 2010, 13, 491-498. [CrossRef]

45. Busch, S. Chemical and Structural Investigations of Biomimetically Grown Fluorapatite-Gelatin Composite Aggregates. Adv. Funct. Mater. 2003, 13, 189-198. [CrossRef]

46. Divya, M. Biopolymer gelatin-coated zinc oxide nanoparticles showed high antibacterial, antibiofilm and anti-angiogenic activity. J. Photochem. Photobiol. B Biol. 2018, 178, 211-218. [CrossRef] [PubMed]

47. Talja, R. Effect of various polyols and polyol contents on physical and mechanical properties of potato starch-based films. Carbohydr. Polym. 2007, 67, 288-295. [CrossRef]

48. Mali, S. Water sorption and mechanical properties of cassava starch films and their relation to plasticizing effect. Carbohydr. Polym. 2005, 60, 283-289. [CrossRef]

49. Turhan, K. Water vapor permeability, tensile properties and solubility of methylcellulose-based edible films. J. Food Eng. 2004, 61, 459-466. [CrossRef]

50. Baumgartner, M. Resilient yet entirely degradable gelatin-based biogels for soft robots and electronics. Materials 2020, 19, 1102-1109. [CrossRef]

51. Patra, A. Quantifying Interactions of Biomolecules with Inorganic Surfaces; Springer Theses; Springer: Cham, Switzerland, 2016; pp. 11-13.

52. Álvarez, N. Device and Strategy for Surface Energy Measurement. Ph.D. Thesis, Universitat Politècnica de Catalunya, Barcelona, Spain, 2018.

53. Li, B. Quick dissolvable, edible and heatstable blend films based on konjac glucomannan-gelatin. Food Res. Int. 2006, 39, 544-549. [CrossRef]

54. Ebeid, E. Thermal Analysis: From Introductory Fundamentals to Advanced Applications; Elsevier: Amsterdam, The Netherlands, 2021.

55. Höhne, G. Differential Scanning Calorimetry; Springer: Berlin, Germany, 2013; pp. 1-19. 